Journal of Teacher Education for Sustainability, vol. 20, no. 1, pp. 46-63, 2018

\title{
Knowledge, Attitudes and Practices of Sustainability: Systematic Review 1990-2016
}

\author{
Walter Alfredo Salas-Zapata, Leonardo Alberto Ríos-Osorio, \\ and Jaiberth Antonio Cardona-Arias \\ University of Antioquia, Medellín, Colombia
}

\begin{abstract}
For any transition towards sustainability to be successful, it is necessary to understand the knowledge, attitudes and practices (KAP) - related to sustainability - in different populations. A systematic review was conducted to identify and analyse KAP studies on sustainability that were reported in the scientific literature during the period of 19902016. Ten studies were found, of which half were conducted among populations in educational environments, i.e., teachers, students and graduates. The KAP results vary among the studies; however, there is a general tendency to investigate aspects related to ecosystems, natural resources, environmental protection and conservation. The present study concludes that it is necessary to conduct KAP studies that include categories that reflect on the wide range of meanings of sustainability and the attitudes and practices that would arise from such perspectives. This finding also reveals dimensions of sustainability usually omitted by KAP studies of sustainability.
\end{abstract}

Keywords: sustainability, education for sustainable development, environmental behaviour, knowledge, attitudes, practices, behaviours

\section{Introduction}

Transition towards sustainability is the change that human groups make to establish harmonious relationships with the natural systems that support them. This transition requires profound and radical changes in their beliefs and values, patterns of social behaviour, management regimes and multilevel governance in certain societies (Westley et al., 2011). Thus, to understand and/or promote the transition in a particular group of people, it would be necessary to examine at least three aspects: knowledge or beliefs, value systems and actions that, hypothetically, should be consistent with such belief and valuation schemes.

However, one aspect that makes such a transition complex to understand is the polysemy of the concept of sustainability. This concept has as many confusing and diverse meanings as the disciplinary areas and political contexts in which it is used (Balaceanu \& Apostol, 2014; Besong \& Holland, 2015; Bolis, Morioka, \& Sznelwar, 2014; Ciegis, 
Ramanauskiene, \& Martinkus, 2009; Glavic, 2007; Mebratu, 1998). It is logical to assume that the imagined and heterogeneous perceptions of sustainability lead to modes of action that are equally heterogeneous. In a systematic review of scientific production related to sustainability issues, Salas-Zapata et al. (2017) revealed that researchers did not tend to define the concept of sustainability explicitly and that, among those who defined it, there were at least three different ways of understanding it: the first was a teleological understanding that assumed sustainability as a vision; the second was an ontological understanding that assumed sustainability as the behaviour of specific systems; and the third was an approach that involved the incorporation of environmental criteria into human activities. That study also revealed that the researchers did not use methodologies consistent with such conceptions of sustainability, which would support the hypothesis that diverse conceptions of sustainability were reflected in heterogeneous actions.

In this regard, the studies related to knowledge, attitudes and/or practices (KAP) provide a research typology, which is relevant to the initial approach to sustainability perspectives that prevail in different populations, as a basis to explore the potential sources of the success or failure of initiatives that promote sustainability.

The KAP model relates cognitive, affective and behavioural elements that are subject to intervention from communicative actions that increase the level of knowledge, change attitudes and improve practices. Knowledge refers to cognitive elements associated with mental actions such as perception, memory, learning and prediction during the processing of information. Attitudes are affective responses to an object, which depend on beliefs, values (Bohner \& Wanke, 2002), personal experiences, encounters with others (Kerin, Hartley, \& Rudelius, 2009), the processes of socialisation and, in general, direct or indirect contact with reality (Donahue $\&$ Miller, 2006). Practices denote specific actions that are directly related to processes that are cognitive (knowledge) and affective (attitudes) to the extent that all human acts are consistent with their values, beliefs, understanding, culture and other socialisation processes (Heimlich \& Ardoin, 2008).

Despite the relevance of KAP studies, references to sustainability research with this sort of typology are scarce, and although there are a few records of positive attitudes towards sustainability education among students and teachers, this group is characterised by a low level of knowledge (Burmeister \& Eilks, 2013), a low adhesion to sustainability practices among university students (de Castro \& Jabbour, 2013), little understanding and awareness among students of what sustainability is (Green, 2013) and negligible improvements in the knowledge and awareness required to create a more sustainable society among students taking courses that incorporate sustainable development issues (Lozano \& Young, 2013).

These records demonstrate the existence of a small number of studies that evaluate the three domains of the KAP model, as well as the absence of reviews that systematise the studies available on this topic. Ultimately, under a scenario of environmental concern such as the present one, which demands transitioning towards sustainability, a study must be able to synthesise the knowledge of sustainability and its different perspectives, the types of populations who share these perspectives, the most relevant attitude types and the categories of human action through which these perspectives produce such visions of sustainability, as well as the geographical and temporal profile of the studies. 
The present study was designed with the objective of identifying and analysing KAP studies on sustainability reported in the scientific literature during the period of 1990-2016. These types of studies have such advantages as gathering, evaluating and synthesising multiple studies, reducing biases, identifying trends or sources of heterogeneity in the results and presenting greater external validity or possibilities for extrapolating the results (Cardona-Arias, Higuita-Gutierrez, \& Ríos-Osorio, 2015).

In particular, a systematic review of KAP studies on sustainability is a valuable research alternative because 1) it can correct problems such as the semantic heterogeneity inherent in the concept of sustainability through the integration of plural and divergent views of the concept in different groups of people; 2) it permits the KAP of sustainability to be analysed in different areas such as energy, transport, agriculture and water management, as well as the unification of conceptual criteria between these sectors to understand the innovations and transitions that certain groups of people make to solve environmental problems; and 3) it could be a valuable tool for examining barriers of individual behaviour that may be determinants of the success of economic, social, political and technological decisions aimed at achieving more sustainable regions and societies.

\section{Methodology}

\section{Type of Study}

A systematic review of the scientific literature. Protocol for the search and selection of studies according to the Preferred Reporting Items for Systematic Reviews and MetaAnalyses (PRISMA) publishing recommendations.

\section{Search and Identification of Studies}

Four search strategies were used, namely knowledge attitude practice AND sustainable development; knowledge attitude practice AND sustainability; KAP AND sustainable development; and KAP AND sustainability.

Search was performed in multidisciplinary databases: MEDLINE/PubMed, ScienceDirect, SciELO and JSTOR. A manual search was also performed in Google Scholar to improve comprehensiveness of the search. Some of the syntax employed were as follows: (knowledge attitude practice[Title/Abstract]) AND sustainability[Title/ Abstract]; ((knowledge[Title/Abstract] AND attitude[Title/Abstract] AND practice[Title/ Abstract])) AND sustainable development[Title/Abstract]; TITLE-ABSTRKEY(knowledge AND attitude AND practice) and TITLE-ABSTR-KEY(sustainable development); (ti:KAP OR tb:KAP OR ab:KAP) AND ab:(sustainable development); and (ti:((ab:((KAP) AND (sustainability))))).

\section{Screening}

The studies identified were screened by applying three inclusion criteria: 1) the search terms had to be included in the title/abstract; 2 ) the studies had to be original; and 3) the primary objective of the research was to describe or analyse KAP as related to sustainability. The removal of duplicate studies was performed at the end of this stage. References of the screened articles were reviewed; it was ensured that the search did not have any temporal restriction of a retrospective manner, and the inclusion of 
studies published up to 31 August 2016 was done prospectively. It is worth noting that in this review the study period was limited to 1990-2016, as studies prior to this period were not found.

\section{Selection}

The excluded studies comprised the studies in which the KAP model was used to assess the impact and/or sustainability of programmes, projects and other inventions, articles which only assessed the effect of a single category of KAP or when KAP was a secondary outcome of an intervention, and studies that did not make the results explicit for each of the KAP domains.

\section{Evaluation of Repeatability and Quality of Studies}

The search and selection protocol was applied independently by two researchers to ensure the reproducibility of the selection of studies; it was determined a priori that the differences would be resolved by consensus, in the same manner in which the extraction of information occurred. Evaluation of the quality of studies was based solely on the criterion of internal validity, which was determined by evaluating potential risks of selection and information bias, and in cases that required an assessment of potential variables of confusion. It is worth noting that external validity was not evaluated given that a majority of studies were performed in samples by convenience.

\section{Data Collection}

The variables of the study were title, authors, country, year, type and size of the population, measuring tools and results, and measurement tools for the domains of knowledge, attitudes and practices, for which extraction was completed independently by two investigators using a Microsoft Excel spreadsheet.

\section{Data Analysis}

A qualitative synthesis of the studies was performed for each of the variables described.

\section{Results}

The initial search identified 40,295 studies, which were limited to 159 by including the search terms in the title or abstract, followed by the application of the inclusion and exclusion criteria, which further systematised the results to 10 studies (Fig. 1). The studies were developed primarily in Asia $(n=4)$ and Africa $(n=3)$; only one study was from Europe, and two were from America. Only two studies were developed prior to 2006. The populations predominantly included teachers $(n=1,190)$ and students $(n=641)$, with a total of 2,853 individuals; two studies were qualitative and investigated KAP using interviews, and the remaining eight were quantitative studies based on surveys (Table 1). 


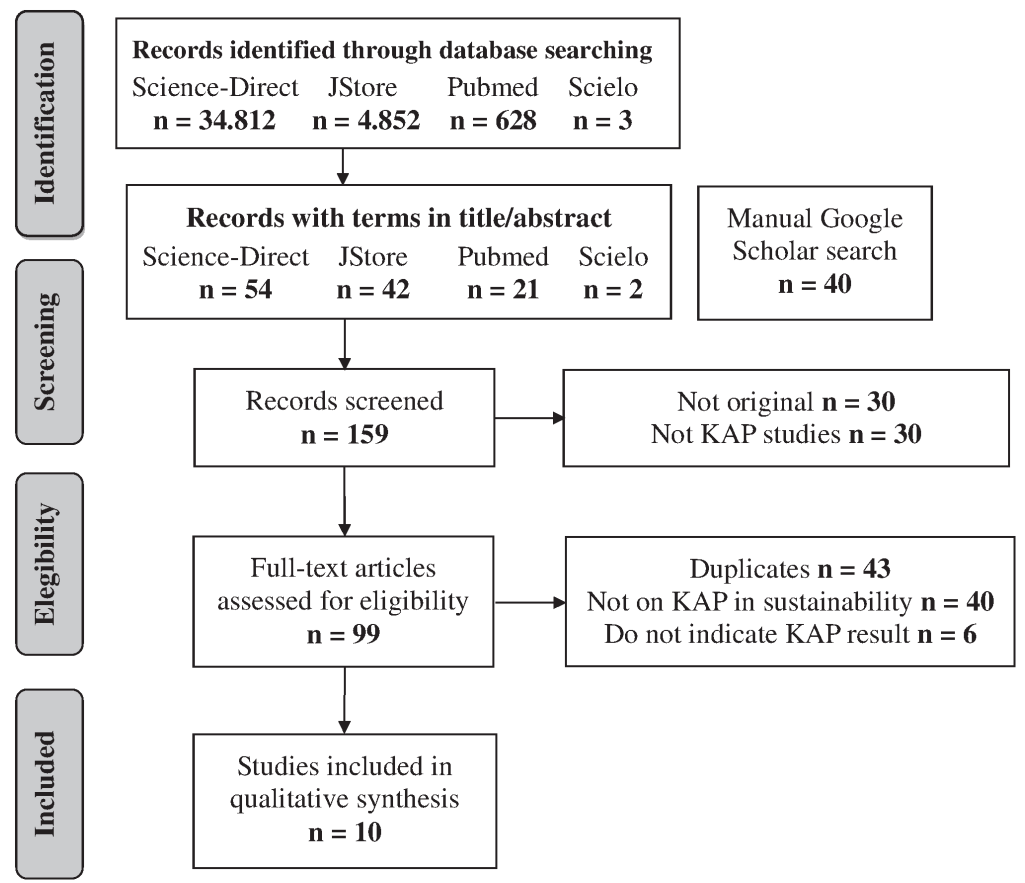

Figure 1. Flow diagram of study selection

In general terms, the objectives referred to in the different studies indicate two trends. The first trend involves the internalist studies, which intend to demonstrate the impact of proposed student training or the training and work that the trainees perform in the classroom during the teaching process, that is, the learning associated with the transmission of knowledge about sustainability-related issues. The other trend involves the externalist studies, which intend to demonstrate the impact on KAP that communities, public and private institutions, and civil society organisations have regarding issues related to sustainability (Table 1 ).

Table 1

Description of Studies According to Year, Country, Objective and Study Population

\begin{tabular}{|c|c|c|c|c|}
\hline Author & Year & Location & Objective & Population \\
\hline $\begin{array}{l}\text { Mansaray } \\
\text { et al. }\end{array}$ & 1998 & Nigeria & $\begin{array}{l}\text { Determine the prevailing knowledge and } \\
\text { attitudes of Nigerian secondary school } \\
\text { teachers regarding salient environmental } \\
\text { concepts and environmental education }\end{array}$ & $\begin{array}{l}360 \text { art and } \\
\text { science } \\
\text { teachers }\end{array}$ \\
\hline $\begin{array}{l}\text { Mlipha } \\
\text { and } \\
\text { Manyatsi }\end{array}$ & 2005 & Swaziland & $\begin{array}{l}\text { Investigate and establish basic environ- } \\
\text { mental KAP of secondary and high } \\
\text { school teachers in Swaziland }\end{array}$ & $\begin{array}{l}685 \text { secondary } \\
\text { teachers }{ }^{\mathrm{a}}\end{array}$ \\
\hline Hai et al. & 2010 & Vietnam & $\begin{array}{l}\text { Study the factors that inuence the under- } \\
\text { standing of the concept, as well as the } \\
\text { content indicators of sustainable develop- } \\
\text { ment for health and environmental aspects }\end{array}$ & 546 residents $^{\mathrm{a}}$ \\
\hline
\end{tabular}


Sequel to Table 1.

\begin{tabular}{|c|c|c|c|c|}
\hline $\begin{array}{l}\text { Kioko and } \\
\text { Kiringe }\end{array}$ & 2010 & Kenya & $\begin{array}{l}\text { Investigate the role of environmental and } \\
\text { wildlife clubs, as well as formal education } \\
\text { in environmental and wildlife conserv- } \\
\text { ation, in Maasailand in southern Kenya } \\
\text { by comparing youth with different levels } \\
\text { of schooling and by comparing formally } \\
\text { and informally educated youth }\end{array}$ & $\begin{array}{l}160 \text { secondary } \\
\text { and } 290 \\
\text { primary } \\
\text { students }^{\mathrm{a}}\end{array}$ \\
\hline Cardwell & 2011 & Canada & $\begin{array}{l}\text { Understand how the Canadian public } \\
\text { currently perceive and behave with } \\
\text { regards to global environmental change }\end{array}$ & $\begin{array}{l}22 \text { adults from } \\
\text { the general } \\
\text { population }^{\mathrm{b}}\end{array}$ \\
\hline $\begin{array}{l}\text { Wan } \\
\text { Nur'ashiqin } \\
\text { et al. }\end{array}$ & 2011 & Malaysia & $\begin{array}{l}\text { Diagnose the domains of KAP among the } \\
\text { University Kebangsaan Malaysia (UKM) } \\
\text { Bangi campus community }\end{array}$ & $\begin{array}{l}191 \text { students } \\
\text { and } 45 \text { staff }^{\mathrm{a}}\end{array}$ \\
\hline Awang et al. & 2013 & Malaysia & $\begin{array}{l}\text { Examine and discuss the levels of know- } \\
\text { ledge, attitudes and recycling practice } \\
\text { among young civil servants at their } \\
\text { workplaces }\end{array}$ & $\begin{array}{l}244 \text { young } \\
\text { people } 20-40 \\
\text { years old }\end{array}$ \\
\hline $\begin{array}{l}\text { Johar and } \\
\text { Razak }\end{array}$ & 2014 & Malaysia & $\begin{array}{l}\text { Describe the environmental consciousness } \\
\text { among communities in a developing } \\
\text { country }\end{array}$ & $\begin{array}{l}140 \text { home- }^{-} \\
\text {owners }^{\mathrm{a}}\end{array}$ \\
\hline Da Silva & 2015 & Guyana & $\begin{array}{l}\text { Examine the perceptions, level of aware- } \\
\text { ness and knowledge of teachers and their } \\
\text { ability to foster skills and infuse inform- } \\
\text { ation about the conservation of mangroves } \\
\text { into their teaching }\end{array}$ & 100 teachers $^{\mathrm{a}}$ \\
\hline $\begin{array}{l}\text { Fernández- } \\
\text { Manzanal } \\
\text { et al. }\end{array}$ & 2015 & Spain & $\begin{array}{l}\text { Clarify whether a university education } \\
\text { contributes to developing future profes- } \\
\text { sionals that help society become more } \\
\text { sustainable }\end{array}$ & 70 graduates $^{b}$ \\
\hline
\end{tabular}

a Survey, ${ }^{\mathrm{b}}$ In-depth interviews

In the eight quantitative studies, tools primarily consisted of surveys with Likert type questions and scores ranging from $0-100$, with greater than 50 being considered a good result and greater than 80 being excellent. Only two studies made the results explicit according to the reliability scale analysis, with a Cronbach $\alpha$ of greater than 0.70 (Awang et al. 2013 and Da Silva 2015).

Table 2 summarises the KAP profile reported in each study, highlighting the following findings: $i$ ) studies with teachers had a high level of heterogeneity, as some reported a low level of knowledge, with negative attitudes and low participation in environmental protection practices (Mansaray, Ajiboye, \& Audu, 1998), whereas in others, the KAP was highly satisfactory (Da Silva, 2015; Mlipha \& Manyatsi, 2005); ii) something similar occurred in the research with students, who exhibited poor knowledge but excellent attitudes and practices (Kioko \& Kiringe, 2010), as well as in studies with unsatisfactory results in the practice domain (Wan Nur'ashiqin, Er, Ali, Lyndon, \& Hashim, 2011); and iii) the study with adults conducted by Cardwell (2011) reported favourable knowledge, attitudes of scepticism and an excellent level of practice, whereas in younger people, Awang (2013) reported moderate to good levels in their KAP. 
Table 2

Description of KAP of the Included Studies

\begin{tabular}{|c|c|c|c|}
\hline Author & Knowledge & Attitudes & Practices \\
\hline $\begin{array}{l}\text { Mansaray } \\
\text { et al. } \\
(1998)\end{array}$ & $\begin{array}{l}\text { Teachers with a low level } \\
\text { of knowledge, especially } \\
\text { in the arts group }\end{array}$ & $\begin{array}{l}\text { Negative attitudes towards } \\
\text { the environment in all } \\
\text { three groups }\end{array}$ & $\begin{array}{l}\text { Have never worked with } \\
\text { environmental education } \\
\text { issues }\end{array}$ \\
\hline $\begin{array}{l}\text { Mlipha and } \\
\text { Manyatsi } \\
(2005)\end{array}$ & $\begin{array}{l}\text { Teachers with a high level } \\
\text { of knowledge about the } \\
\text { environment }\end{array}$ & $\begin{array}{l}\text { High frequency of positive } \\
\text { attitudes }\end{array}$ & $\begin{array}{l}\text { Participation in tree } \\
\text { planting and litter } \\
\text { removal }\end{array}$ \\
\hline $\begin{array}{l}\text { Hai et al. } \\
(2010)\end{array}$ & $\begin{array}{l}\text { Low level of knowledge } \\
\text { about environmental } \\
\text { protection and health }\end{array}$ & $\begin{array}{l}\text { Low inclination to partic- } \\
\text { ipate in programmes }\end{array}$ & $\begin{array}{l}\text { Low participation in } \\
\text { environmental and } \\
\text { health activities }\end{array}$ \\
\hline $\begin{array}{l}\text { Kioko and } \\
\text { Kiringe } \\
(2010)\end{array}$ & $\begin{array}{l}\text { Students with little know- } \\
\text { ledge of the importance } \\
\text { of conservation }\end{array}$ & $\begin{array}{l}\text { Excellent attitude towards } \\
\text { conservation }\end{array}$ & $\begin{array}{l}\text { High participation in } \\
\text { conservation activities }\end{array}$ \\
\hline $\begin{array}{l}\text { Cardwell } \\
(2011)\end{array}$ & $\begin{array}{l}\text { Adults with high local } \\
\text { environmental awareness } \\
\text { and low global awareness }\end{array}$ & $\begin{array}{l}\text { Scepticism over causes and } \\
\text { impacts of some initiatives }\end{array}$ & $\begin{array}{l}\text { High participation in } \\
\text { recycling and energy } \\
\text { consumption reduction }\end{array}$ \\
\hline $\begin{array}{l}\text { Wan } \\
\text { Nur'ashiqin } \\
\text { et al. (2011) }\end{array}$ & $\begin{array}{l}\text { Teachers and students that } \\
\text { understand the concept of } \\
\text { a sustainable campus and } \\
\text { whose knowledge differs } \\
\text { from that of the adminis- } \\
\text { trative staff }\end{array}$ & $\begin{array}{l}\text { Teachers and students con- } \\
\text { sider it important to im- } \\
\text { plement sustainable campus } \\
\text { initiatives in university } \\
\text { programmes and to adopt } \\
\text { sustainable lifestyles }\end{array}$ & $\begin{array}{l}\text { Reduction, recycling and } \\
\text { reuse is only practised by } \\
\text { the staff; a preference for } \\
\text { using private transport- } \\
\text { ation exists in both } \\
\text { groups }\end{array}$ \\
\hline $\begin{array}{l}\text { Awang } \\
\text { et al. (2013) }\end{array}$ & $\begin{array}{l}\text { Young people with good } \\
\text { knowledge regarding } \\
\text { recycling }\end{array}$ & $\begin{array}{l}\text { Positive approach to } \\
\text { recycling }\end{array}$ & $\begin{array}{l}\text { A moderate level of } \\
\text { recycling at work }\end{array}$ \\
\hline $\begin{array}{l}\text { Johar and } \\
\text { Razak } \\
(2015)\end{array}$ & Low scores in general & Low scores & Low scores \\
\hline $\begin{array}{l}\text { Da Silva } \\
(2015)\end{array}$ & $\begin{array}{l}\text { Teachers with good know- } \\
\text { ledge of mangroves and } \\
\text { their conservation }\end{array}$ & Positive attitude & $\begin{array}{l}\text { Incorporation of these } \\
\text { themes into their } \\
\text { teaching }\end{array}$ \\
\hline $\begin{array}{l}\text { Fernández- } \\
\text { Manzanal } \\
\text { et al. (2015) }\end{array}$ & $\begin{array}{l}\text { Participants were aware } \\
\text { of such themes as environ- } \\
\text { mental management, pre- } \\
\text { servation of natural spaces } \\
\text { and environmental impact } \\
\text { assessment; they also } \\
\text { understood hurdles to } \\
\text { environmental actions }\end{array}$ & $\begin{array}{l}\text { Low willingness to partic- } \\
\text { ipate and propose projects } \\
\text { and strategies, waiting } \\
\text { until others take the initi- } \\
\text { ative (procrastination) on } \\
\text { environmental actions }\end{array}$ & $\begin{array}{l}\text { Few graduates partic- } \\
\text { ipate in environmental } \\
\text { activities }\end{array}$ \\
\hline
\end{tabular}

The tools used in all studies were organised into a list, synthesised and then classified by emerging categories in each of the three domains (Appendix 1). A total of fourteen categories were identified, six within the domain 'knowledge', five within the domain 'attitudes' and three within the domain 'practices' (Table 3). 
Table 3

Categories Identified in Each Domain in the Included Studies

\begin{tabular}{cl}
\hline Domain & \multicolumn{1}{c}{ Category } \\
\hline Knowledge & Knowledge of environmental problems \\
\cline { 2 - 2 } & Knowledge of a particular ecosystem \\
\cline { 2 - 2 } & Ecological knowledge of their region \\
\cline { 2 - 2 } & Knowledge of concepts \\
\cline { 2 - 2 } & Knowledge of behaviours or actions that promote sustainability \\
\hline Attitudes & Perceptions of incentives and restrictions for performing actions that \\
& Momote sustainability \\
\cline { 2 - 2 } & Valuation (importance) attributed to certain actions \\
\cline { 2 - 2 } & Satisfaction with themselves and others \\
\cline { 2 - 2 } & Readiness to take action \\
\cline { 2 - 2 } & Feelings and concerns that environmental problems generate \\
\hline Practices & Individual actions \\
\cline { 2 - 2 } & Actions linked to the actions of others \\
\cline { 2 - 2 } & Actions of other people or organisations \\
\hline
\end{tabular}

\section{Discussion}

The concept of sustainability has diverse and sometimes contradictory meanings, which depend on the contexts the term is used. This variety of applications and meanings often leads to a lack of clarity that hinders its operationalization (Mebratu, 1998; Glavic, 2007; Ciegis et al., 2009; Balaceanu and Apostol, 2014; Bolis et al., 2014). In part, this ambiguity is due to sustainability being a complex phenomenon which can be simultaneously assumed as a set of goals and purposes of human organisations, the behaviour of certain systems - the capacity of social-ecological systems to last in time and the incorporation of environmental, social and economic variables, or criteria, into certain activities (Salas et al., 2017).

In such a sense, when exploring knowledge, attitudes and practices related to sustainability it is reasonable to find heterogeneity. According to these findings, participants' knowledge on sustainability is heterogeneous and has an environmental character. In some cases, participants show an elevated knowledge level, while in others, a low one. In both settings, such knowledge seems to have an environmental character. Regarding attitudes, participants have positive attitudes towards sustainability, but their willingness to participate in projects or programmes related does not necessarily point at the same direction. Results on practices are equally divergent.

\section{Knowledge on Sustainability}

Knowledge, as described by the studies, enables the identification of the participants' tendency to understand sustainability as an environmental issue related to ecosystems or natural resources. Consequently, knowledge of sustainability, as reported in the studies, is related to specific ecosystems or resources, their care, protection and preservation, or environmental problems. It follows that low or unsatisfactory scores in this domain 
indicate that the participants in these studies had little knowledge of certain ecosystems, environmental problems or environmentally friendly practices. This type of knowledge is, in turn, reflected in the six categories described in Table 3.

The present study is in contrast with the ways of understanding sustainability that have been reported in the scientific literature. For example, one of the studies assumes sustainability is a synonym for sustainable development and therefore has a political or humanitarian meaning (Salas-Zapata et al., 2017). This view of sustainability was not explored by the KAP studies, and, consequently, it is not possible to determine whether the participants consider intergenerational equity to be a component of sustainability. This may possibly explain why these studies used tools that had an environmental orientation.

Sustainability can also be understood as balance, equilibrium and society's ability to reorganise natural systems after disturbances (Salas-Zapata et al., 2017). This manner of understanding sustainability was also unclear in the examined KAP studies. As in the previous example, this result may be due to the fact that the items or variables used were not aimed at exploring this way of understanding sustainability, but it should also be noted that theoretical developments in the concept of sustainability are still incipient. As a result, the selection or construction of tools by researchers may be a reflection of these developments.

Sustainability can also be understood as the incorporation of environmental criteria into human activities (Salas-Zapata et al., 2017). Apparently, this was the perspective used in the KAP studies insofar as the questions were directed in such a way as to understand what the participants knew about their surroundings, its problems, ecosystems and environmental actions.

Half of the studies reviewed were conducted with students and teachers or graduates. In other words, half of these studies are associated with education. In this regard, it should be noted that the synthesis of results has revealed findings that are consistent with KAP studies conducted in the field of sustainability education. For example, the study conducted by Burmeister and Eilks (2013), which included students and teachers, revealed that the participants' knowledge on sustainability was limited and had poor theoretical support. Similarly, the study conducted by Green, which included North American university students, demonstrated that despite being provided with content regarding sustainability and the environment from a regulatory or legal perspective in an introductory economics course, this mechanism failed to improve the students' understanding and apprehension towards issues of sustainability and the environment (Green, 2013).

Another aspect that was not immediately apparent in the selected studies is the exploration of barriers to knowledge. This finding contrasts with the results of several KAP studies in the field of sustainability education in which researchers examined aspects related to the learning of specific knowledge. Kataria et al. (2013) described some perceptions of employers about the most effective methods for incorporating topics or initiatives related to sustainability. For the chemical engineering students in the Aziz study group, it was evident that problem-based learning produced or developed knowledge and significant behavioural changes towards sustainable development (Aziz, Yusof, Udin, \& Yatim, 2013), and Lankester (2013) suggested the presence of knowledge limitations in learning about sustainability, which affected changes in perspectives and related practices. 


\section{Attitudes Related to Sustainability}

The studies analysed demonstrate that, in general, participants have a positive attitude towards sustainability, but their willingness to actively participate accordingly does not necessarily correspond to this attitude. This means that participants tend to value important environmental issues such as the conservation and protection of the environment and ecosystems, practices such as recycling and the existence of sustainability programmes and projects; however, this positive valuation does not appear to translate into a willingness to be involved with programmes or projects and is even less influential in regard to pursuing environmental initiatives.

Burmeister and Eilks (2013) demonstrated that students and teachers reported positive attitudes towards education on the topic of sustainability. The results from Burns (2013) indicated that teachers had a greater awareness of the importance and need to incorporate sustainability into higher education. For their part, Du et al. (2013), in their Chinese population based study, alluded to the fact that sustainability, particularly its incorporation in curricula, increasingly acquired greater importance in higher education. Similarly, Delong and McDermott (2013), who evaluated the attitude of administrators towards the incorporation of sustainability principles into programmes related to marketing and undergraduate education, confirmed the need and relevance of incorporating sustainability into marketing and business courses.

As in the case of knowledge, the attitudes explored by KAP studies have an environmental orientation. The analysis of variables related to attitudes was broken down into five categories; all of them were related to the environment. Consequently, other attitudes that might also be related to sustainability such as motivation, importance, satisfaction and disposition towards solidarity, social responsibility and equity were ignored. These are attitudes, which are not related to society-nature interactions and may also affect the transition towards sustainability.

\section{Practices Related to Sustainability}

The studies reviewed reported practices related to sustainability such as recycling, the incorporation of environmental issues and environmentally-friendly activities such as those that reduce energy consumption, tree planting and the use of public transport. The results that included the participation of people in these activities are, however, divergent.

The practices described in the studies are consistent with the attitudes found in them. Mansaray et al. (1998), Hai et al. (2010), Johar and Razak (2015) and FernándezManzanal et al. (2015) reported low scores in sustainability practices and/or low participation in environmental activities, as well as found negative attitudes or a low disposition and willingness to participate. Kioko and Kiringe (2010), Mlipha and Manyatsi (2005) and Da Silva (2015) found positive attitudes, or high scores, for sustainability practices such as a high participation in environmental activities, including the incorporation of sustainability and tree planting.

However, attitudes are not the only factor related to behaviours and practices. There are elements in the individuals' environment that affect these practices that are not necessarily explored in the KAP studies. Redman (2013) demonstrated that although a group of young people received sustainability education, this did not contribute to the 
adoption of sustainable behaviours; this result appeared to be related to the cultural and social environment of the participants. Similarly, Lozano indicated that the awareness of changes - towards sustainability - by a group of students might be related to the high number of students per course (Lozano \& Young, 2013). In this regard, other studies pointed out that environmental behaviours, e.g., recycling, might be influenced by factors of the immediate environment of the participants that transcended the individual sphere like family background and household infrastructure (Kolbe, 2015). It should be noted that one of the limitations of the KAP studies is that they only address the individual sphere of the participants.

As for knowledge and attitudes, the practices investigated in these studies also have an environmental orientation and ignore the social aspects of sustainability. This implies that practices of cooperation, altruism and reciprocity, which are necessary for the sustainable management of certain ecosystems (Ostrom, 2011), deserve to be studied; paradoxically, however, the tools used by the KAP studies do not allow this aspect to be analysed.

\section{Challenges of Education for Sustainable Development}

Among other objectives, Education for Sustainable Development (EDS) aims "[at reorienting] education and learning so that everyone has the opportunity to acquire the knowledge, skills, values and attitudes that empower them to contribute to sustainable development" (UNESCO, 2014, p. 14). This systematic review brought to light two aspects that seem to be problematic for Education for Sustainable Development: the complexity of sustainability and of human behaviour inconsistency.

Among the limitations of this study is the high degree of heterogeneity of the categories and tools used to evaluate the KAP of sustainability, which prevented the implementation of a meta-analysis for the scores of each domain. Another aspect that limits the scope of the findings of this study is the environmentalist bias presented by the selected studies. The implied trend in the selected studies, to assume sustainability as being 'environmental', led automatically to circumscribing not only knowledge but also attitudes and practices to this field, which inevitably resulted in omitting aspects that might be more important for promoting the transition towards sustainability such as adaptive capacity, creativity to solve environmental problems and cooperation to resolve conflicts.

This heterogeneity of categories may have its origin in the complexity of the phenomenon of sustainability. Since sustainability can mean, at the same time, a purpose, a dynamic behaviour and a set of social-ecological criteria (Salas-Zapata et al., 2017), the variety of items in knowledge is not necessarily coherent with the items in attitudes and practices. This lack of coherence among items of the studies reviewed makes it difficult for findings to be synthesised and for hypotheses on the kind of knowledge and attitudes worth exploring to be formulated; particularly at any time a project aims at modifying practices of certain human groups.

From the same perspective, ESD faces the problem of human behaviour inconsistency. Consistency can be defined as the degree to which knowledge and attitudes are transferable to practices (Suarez, 2008). Understanding the factors that influence consistency between knowledge, attitudes and practices is necessary for educational processes, 
since it would allow practitioners to design strategies adjusted accordingly so that education develops into behavioural outcomes. However, the heterogeneity of categories used in KAP studies would prevent practitioners from considering those factors and using scientific evidence to support teaching-learning processes aimed at improving environmental behaviours.

From this perspective, future research on the study of knowledge, practices and attitudes on sustainability in different sectors requires a reconstruction of the categories that comprise each domain in such a way that the tools used permit a global understanding of the actions and visions that can enhance or impede the transition towards sustainability.

\section{Conclusion}

Studies on knowledge, attitudes and practices related to sustainability tend to assume sustainability as being the environmental character of something. Thus, the KAP studies analysed in this systematic review focused on exploring environmental knowledge (on ecosystems, natural resources and environmentally-friendly practices). With regards to attitudes, these studies also explored environmental positions by inquiring about the importance and value that people place on environmental issues and practices. A similar finding is observed in the practices described by these studies, as they are associated with environmentally-friendly practices such as recycling, the incorporation of environmental themes and energy conservation.

The studies analysed did not explore other perspectives towards sustainability, such as intergenerational equity, when sustainability is assumed as sustainable development, or adaptability of the relationship between humans and ecosystems. Apparently, for the same reason, they did not inquire about attitudes and practices concerning the relationship between human beings that is also necessary to ensure sustainability. Attitudes such as a concern for the distribution of benefits and externalisation of the costs of human activities, responsible behaviour towards others and cooperation to resolve collective problems were not a focus of interest in these studies. This finding suggests a need to conduct KAP studies that address the perspectives of sustainability that were ignored in the KAP studies reviewed.

\section{References}

Awang Besar, T., Hassan, M., Bolong, J., \& Abdullah, R. (2013). Exploring the levels of knowledge, attitudes and environment-friendly practices among young civil servants in Malaysia. Pertanika Journal of Social Sciences \& Humanities, 21 (spec. July), 21-38.

Aziz, A. A., Yusof, K. M., Udin, A., \& Yatim, J. M. (2013). Development of students' knowledge-behavioural changes in relation to sustainability through a case study. Procedia - Social and Behavioral Sciences, 102(0), 568-576. doi: http://dx.doi.org/ 10.1016/j.sbspro.2013.10.773.

Balaceanu, C., \& Apostol, D. (2014). The perspective of concept sustainability. Procedia-Social and Behavioral Sciences, 116, 2257-2261. doi: http://dx.doi.org/ 10.1016/j.sbspro.2014.01.555. 
Besong, F., \& Holland, C. (2015). The dispositions, abilities and behaviours (DAB) framework for profiling learners' sustainability competencies in higher education. Journal of Teacher Education for Sustainability, 17(1), 5-22

Bohner, G., \& Wanke, M. (2002). Attitudes and attitude change. East Sussex, United Kingdom: Psychology Press.

Bolis, I., Morioka, S. N., \& Sznelwar, L. I. (2014). When sustainable development risks losing its meaning. Delimiting the concept with a comprehensive literature review and a conceptual model. Journal of Cleaner Production, 83, 7-20. doi: http://dx.doi. org/10.1016/j.jclepro.2014.06.041.

Burmeister, M., \& Eilks, I. (2013). An understanding of sustainability and education for sustainable development among German student teachers and trainee teachers of chemistry. Science Education International, 24(2), 167-194.

Burns, H. (2013). Meaningful sustainability learning: A study of sustainability pedagogy in two university courses. International Journal of Teaching \& Learning in Higher Education, 25(2), 166-175.

Cardona-Arias, J., Higuta-Gutierrez, F., \& Ríos-Osorio. (2015). Revisiones sistemáticas de la literatura científica. Medellín: Fondo Editorial Universidad Cooperativa de Colombia.

Cardwell, F. (2011). Knowledge, attitudes and practices of global environment change and health: Toward sustainable behavior change?. (Master), McMaster University, Hamilton.

Ciegis, R., Ramanauskiene, J., \& Martinkus, B. (2009). The concept of sustainable development and its use for sustainability scenarios. Engineering Economics, 2(62), 28-37.

Da Silva, P. N. B. (2015). Conservation of mangroves in Guyana: A study of teachers' perceptions, knowledge, attitudes and practices. Research Journal of Chemical and Environmental Sciences, 3(4), 1-8.

De Castro, R., \& Jabbour, C. J. C. (2013). Evaluating sustainability of an Indian university. Journal of Cleaner Production, 61(0), 54-58. doi: http://dx.doi.org/10.1016/ j.jclepro.2013.02.033.

Delong, D., \& McDermott, M. (2013). Current perceptions, prominence and prevalence of sustainability in the marketing curriculum. Marketing Management Journal, 23(2), 101-116.

Donahue, A. K., \& Miller, J. M. (2006). Experience, attitudes, and willingness to pay for public safety. The American Review of Public Administration, 36, 395-418. doi: $10.1177 / 0275074005285666$.

Du, X., Su, L., \& Liu, J. (2013). Developing sustainability curricula using the PBL method in a Chinese context. Journal of Cleaner Production, 61, 80-88. doi: 10.1016/j.jclepro.2013.01.012.

Fernández-Manzanal, R., Serra, L. M., Morales, M. J., Carrasquer, J., RodríguezBarreiro, L. M., del Valle, J., \& Murillo, M. B. (2015). Environmental behaviours in initial professional development and their relationship with university education. Journal of Cleaner Production, 108, Part A, 830-840. doi: http://dx.doi.org/10.1016/ j.jclepro.2015.07.153.

Glavic, P. L. R. (2007). Review of sustainability terms and their definitions. Journal of Cleaner Production, 15, 1875-1885. 
Green, T. L. (2013). Teaching (un)sustainability? University sustainability commitments and student experiences of introductory economics. Ecological Economics, 94(0), 135-142. doi: http://dx.doi.org/10.1016/j.ecolecon.2013.08.003.

Hai, L. T., Hai, P. H., Dung, T. A., \& Hens, L. (2010). Influencing factors on sustainable development: a case study in Quang Tri province, Vietnam. Environment, Development and Sustainability, 12(1), 103-116. doi: 10.1007/s10668-008-9183-y.

Heimlich, J. E., \& Ardoin, N. M. (2008). Understanding behavior to understand behavior change: a literature review. Environmental Education Research, 14(3), 215-237. doi: 10.1080/13504620802148881.

Johar, F., \& Razak, M. R. (2015). The Right Attitude to Sustain the Green Neighbourhoods. Procedia - Social and Behavioral Sciences, 202, 135-143. doi: http://dx.doi. org/10.1016/j.sbspro.2015.08.216.

Kataria, A., Kataria, A., \& Garg, R. (2013). Effective internal communication: A way towards sustainability. International Journal of Business Insights \& Transformation, 6(2), 46-52.

Kerin, R. A., Hartley, S. W., \& Rudelius, W. (2009). Marketing (8th ed.). New York: McGraw-Hill.

Kioko, J., \& Kiringe, J. W. (2010). Youth's knowledge, attitudes and practices in wildlife and environmental conservation in Maasailand, Kenya. Southern African Journal of Environmental Education, 27.

Kolbe, KD. (2015). Knowledge, attitudes and behaviour regarding waste management in a grammar and a comprehensive school in England - results from a school questionnaire. Journal of Teacher Education for Sustainability, 17(1), 58-71.

Lankester, A. J. (2013). Conceptual and operational understanding of learning for sustainability: A case study of the beef industry in north-eastern Australia. Journal of Environmental Management, 119(0), 182-193. doi: http://dx.doi.org/10.1016/ j.jenvman.2013.02.002.

Lozano, R., \& Young, W. (2013). Assessing sustainability in university curricula: exploring the influence of student numbers and course credits. Journal of Cleaner Production, 49(0), 134-141. doi: http://dx.doi.org/10.1016/j.jclepro.2012.07.032.

Mansaray, A., Ajiboye, J. O., \& Audu, U. F. (1998). Environmental knowledge and attitudes of some Nigerian secondary school teachers. Environmental Education Research, 4(3), 329-339. doi: 10.1080/1350462980040307.

Mebratu, D. (1998). Sustainability and sustainable development: historical and conceptual review. Environ Impact Asses Rev, 18, 493-520.

Mlipha, M., \& Manyatsi, D. (2005). Environmental knowledge, attitudes and practices of secondary and high school teachers in Swaziland. Southern African Journal of Environmental Education, 22, 137-150.

Ostrom, E. (2011). El gobierno de los bienes comunes. La evolución de las instituciones de acción colectiva (2 ed.). México DF: Universidad Nacional Autónoma de México.

Redman, E. (2013). Advancing educational pedagogy for sustainability: Developing and implementing programs to transform behaviors. International Journal of Environmental \& Science Education, 8(1), 1-34.

Salas-Zapata, W., Rios-Osorio, L., \& Cardona-Arias, J. (2017). Methodological characteristics of sustainability science: A systematic review. Environment, Development and Sustainability, 19(4), 1127-1140. doi: 10.1007/s10668-016-9801-z. 
Suárez, E., \& Hernández, B. (2008). La consistencia entre los valores, las actitudes y el comportamiento. Notas desde la psicología ambienta. In: Riechmann, J. ¿En qué estamos fallando?. Barcelona: Icaria \& Antrazyt, 334.

Unesco (2014). Roadmap for Implementing the Global Action Programme on Education for Sustainable Development. Paris: United Nations Educational, Scientific and Cultural Organization. Available at http://unesdoc.unesco.org/images/0023/002305/ 230514e.pdf

Wan Nur'ashiqin, W., Er, A. C., Ali, N., Lyndon, N., \& Hashim, H. S. (2011). Diagnosing knowledge, attitudes and practices for a sustainable campus. World Applied Sciences Journal, 13(13), 93-98.

Westley, F., Olsson, P., Folke, C., Homer-Dixon, T., Vredenburg, H., Loorbach, D., ... van der Leeuw, S. (2011). Tipping Toward Sustainability: Emerging Pathways of Transformation. AMBIO, 40(7), 762-780.

Correspondence concerning this paper should be addressed to Associate Professor Walter Salas-Zapata, Calle 70 No. 52 - 21, Ciudad Universitaria, Oficina 5-103, Zip Code: Apartado Aéreo 1226, Medellín, Colombia. Email: walter.salas@udea.edu.co

\section{Appendix 1}

\section{Construct of KAP on Sustainability in Studies Reviewed}

\begin{tabular}{|c|c|c|c|}
\hline Field & Category & Item & Author \\
\hline \multirow{12}{*}{ 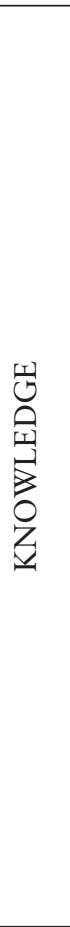 } & \multirow{4}{*}{$\begin{array}{l}\text { Knowledge of } \\
\text { environmental } \\
\text { problems }\end{array}$} & $\begin{array}{l}\text { What changes related to the global change } \\
\text { have you perceived in your health? }\end{array}$ & Cardwell (2011) \\
\hline & & $\begin{array}{l}\text { Which environmental factors affect health } \\
\text { at a community level? }\end{array}$ & Cardwell (2011) \\
\hline & & $\begin{array}{l}\text { What does climate change (global warming) } \\
\text { mean to you? }\end{array}$ & Cardwell (2011) \\
\hline & & $\begin{array}{l}\text { Which are the main problems in mangrove } \\
\text { areas? }\end{array}$ & Da Silva (2015) \\
\hline & \multirow[t]{4}{*}{$\begin{array}{l}\text { Knowledge of } \\
\text { certain ecosystem }\end{array}$} & $\begin{array}{l}\text { Can I identify different mangrove types and } \\
\text { species? }\end{array}$ & Da Silva (2015) \\
\hline & & Do I need help to identify mangrove species? & Da Silva (2015) \\
\hline & & $\begin{array}{l}\text { What are the ecological functions of man- } \\
\text { groves? }\end{array}$ & Da Silva (2015) \\
\hline & & $\begin{array}{l}\text { Would the disappearance of mangroves be } \\
\text { damaging for Guyana? }\end{array}$ & Da Silva (2015) \\
\hline & \multirow{2}{*}{$\begin{array}{l}\text { Ecological know- } \\
\text { ledge of their } \\
\text { region }\end{array}$} & $\begin{array}{l}\text { Are there different types of mangrove in } \\
\text { Guyana? }\end{array}$ & Da Silva (2015) \\
\hline & & $\begin{array}{l}\text { Is it possible to find mangroves in every } \\
\text { administrative district in Guyana? }\end{array}$ & Da Silva (2015) \\
\hline & \multirow[t]{2}{*}{$\begin{array}{l}\text { Knowledge of } \\
\text { concepts }\end{array}$} & $\begin{array}{l}\text { Do I understand the concept of sustainable } \\
\text { campus? }\end{array}$ & $\begin{array}{l}\text { Wan Nur'ashiqin } \\
\text { et al. (2011) }\end{array}$ \\
\hline & & Is the university campus sustainable? & $\begin{array}{l}\text { Wan Nur'ashiqin } \\
\text { et al. (2011) }\end{array}$ \\
\hline
\end{tabular}


Sequel to Appendix 1.

Do you understand the difference between Cardwell (2011) the terms global change, climate change and global warming?

Where do you obtain information about Cardwell (2011) environmental issues?

\begin{tabular}{ll}
\hline What is health? & Cardwell (2011) \\
\hline There was an assessment of the environ- & Johar and Razak \\
mental knowledge about natural resources. & $(2015)$
\end{tabular}

Knowledge of I know about the Guyana Mangrove Restor- Da Silva (2015) behaviors or ation Project and its actions.

actions benefiting I know programs, projects and/or organiz- Cardwell (2011) sustainability ations working on environmental issues in my community.

\begin{tabular}{ll}
\hline $\begin{array}{l}\text { Are you aware of any environmental action } \\
\text { in the university? }\end{array}$ & $\begin{array}{l}\text { Wan Nur'ashiqin } \\
\text { et al. (2011) }\end{array}$ \\
\hline $\begin{array}{l}\text { Is your center or company managed in } \\
\text { accordance to sustainable principles? }\end{array}$ & $\begin{array}{l}\text { Fernández-Man- } \\
\text { zanal et al. (2015) }\end{array}$ \\
\hline $\begin{array}{l}\text { Can recycling practices reduce climate } \\
\text { change? }\end{array}$ & Awang et al. (2013) \\
\hline $\begin{array}{l}\text { Does recycling save energy? } \\
\begin{array}{l}\text { Knows how to separate waste according to } \\
\text { container color. }\end{array}\end{array}$ & Awang et al. (2013) \\
\hline
\end{tabular}

Knows about recycling. Johar and Razak

(2015)

The low carbon development strategies can Da Silva (2015) reduce the impact of climate change.

Nothing can be done with recycled things. Awang et al. (2013)

What can you do to carry out environmen- Cardwell (2011) tally friendly actions?

Perceptions of What difficulties have you had to make part Fernández-Manincentives and of pro-environmental strategies? zanal et al. (2015)

restrictions that Does the merit and demerit system promote Wan Nur'ashiqin may affect behaviors or actions benefiting sustainability sustainability culture in the university? et al. (2011) What are the obstacles to making behavior Fernández-Manchanges (towards environmentally-friendly zanal et al. (2015) behaviors)?

Which incentives promote environmentally- Fernández-Manfriendly actions? zanal et al. (2015)

\begin{tabular}{lll}
\hline & $\begin{array}{l}\text { Motivation and } \\
\text { reasons behind } \\
\text { environmentally }\end{array}$ & $\begin{array}{l}\text { What is the reason behind people's friendly - Cardwell (2011) } \\
\text { or not - behavior towards the environment? }\end{array}$ \\
\cline { 2 - 3 } $\begin{array}{l}\text { fould you like know more about mangroves? } \\
\text { friendly behavior }\end{array}$ & $\begin{array}{l}\text { Would I be interested in learning more about } \\
\text { climate change and development strategies? }\end{array}$ & Da Silva (2015) \\
\hline $\begin{array}{ll}\text { Importance or } \\
\text { relevance given } \\
\text { to certain actions }\end{array}$ & $\begin{array}{l}\text { The conservation of mangroves will gain } \\
\text { importance over time. }\end{array}$ & Da Silva (2015) \\
\cline { 2 - 3 } & $\begin{array}{l}\text { Perceived value of tourism, currency exchange, Kioko and Kiringe } \\
\text { wildlife containment, recreation, employment, (2010) }\end{array}$ \\
\hline
\end{tabular}


Sequel to Appendix 1.

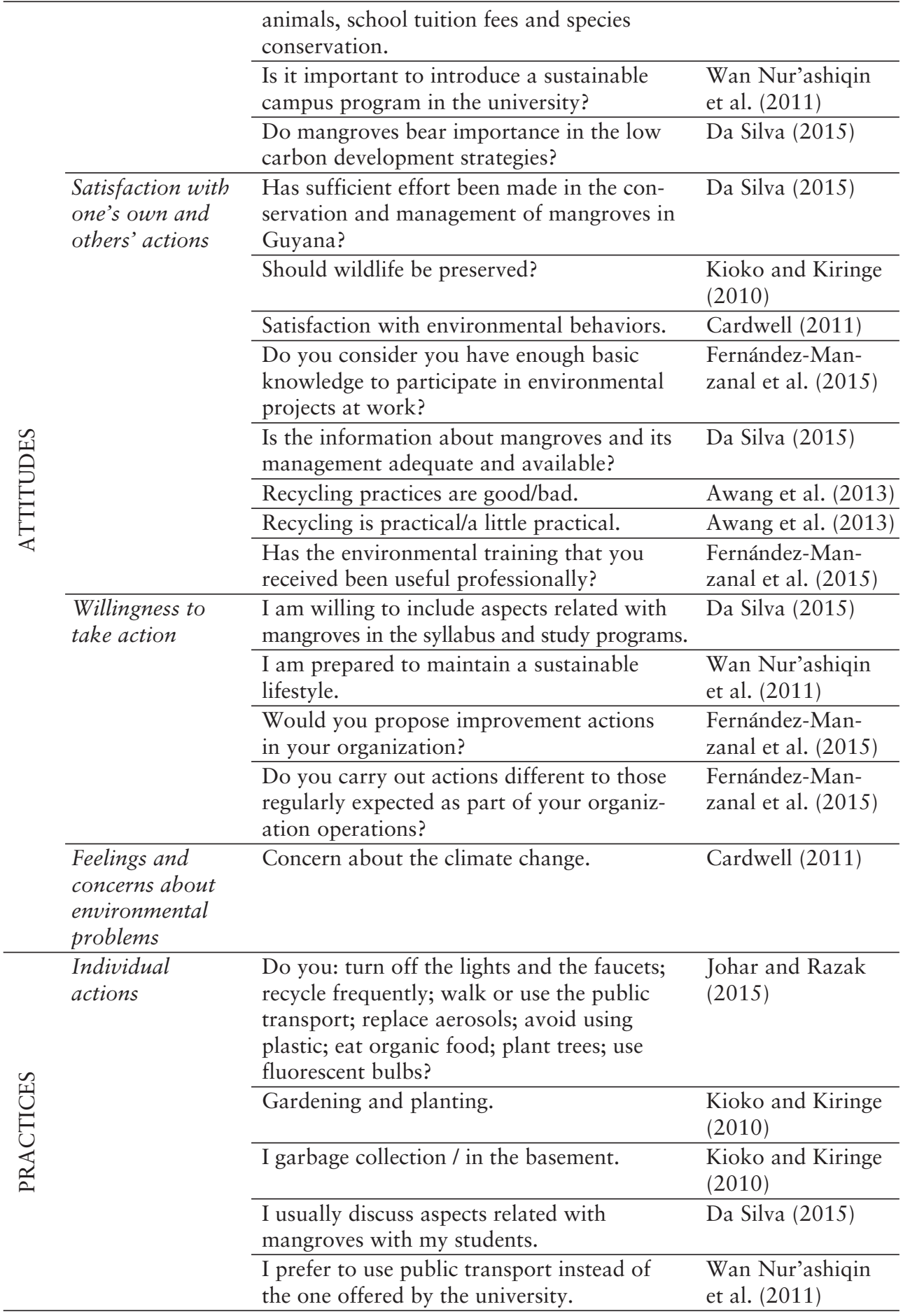


Sequel to Appendix 1.

I make careful use of the services offered by Wan Nur'ashiqin the university. et al. (2011)

I practice the $4 \mathrm{R}$ (refuse, reduce, reuse, recycle).

Wan Nur'ashiqin

I sort garbage according to recycling types. Awang et al. (2013)

I take my students to the field.

Da Silva (2015)

I sort and store recycling material before

Awang et al. (2013) selling it.

Actions related Participation in training programs. Johar and Razak

to those of others (2015)

Do you participate in conservation activities Kioko and Kiringe at home? (2010)

Have you attended workshops and lectures Da Silva (2015) about mangroves conservation?

Have you made part of environmental Fernández-Manstrategies and projects? zanal et al. (2015)

Actions of other Has the Mangroves Restoration Project Da Silva (2015) persons or informed the schools about the mangroves organizations in Guyana?

\begin{tabular}{ll}
\hline $\begin{array}{l}\text { Have you been trained in environmental } \\
\text { matters at work or in your organization? }\end{array}$ & $\begin{array}{l}\text { Fernández-Man- } \\
\text { zanal et al. (2015) }\end{array}$ \\
\hline $\begin{array}{l}\text { My family always reminds me about not } \\
\text { contaminating the environment. }\end{array}$ & Awang et al. (2013) \\
\hline $\begin{array}{l}\text { Did you receive specific training in environ- } \\
\text { mental matters while in college/university? }\end{array}$ & $\begin{array}{l}\text { Fernández-Man- } \\
\text { zanal et al. (2015) }\end{array}$ \\
\hline $\begin{array}{l}\text { People at campus show sustainable } \\
\text { behaviors. }\end{array}$ & $\begin{array}{l}\text { Wan Nur'ashiqin } \\
\text { et al. (2011) }\end{array}$ \\
\hline $\begin{array}{l}\text { Has the Mangroves Restoration Project } \\
\text { provided training in hygiene and health? }\end{array}$ & Da Silva (2015) \\
\hline $\begin{array}{l}\text { Environmental clubs report on problems } \\
\text { and erosion control related to wildlife } \\
\text { preservation. }\end{array}$ & $\begin{array}{l}\text { Kioko and Kiringe } \\
(2010)\end{array}$ \\
\hline
\end{tabular}

